\title{
Strategies for Xylitol Purification and Crystallization: A Review
}

\section{Ernesto A. Martínez, Eliana V. Canettieri, José A. C. Bispo, Marco Giulietti, João B. de Almeida e Silva \& Attilio Converti}

To cite this article: Ernesto A. Martínez, Eliana V. Canettieri, José A. C. Bispo, Marco Giulietti, João B. de Almeida e Silva \& Attilio Converti (2015) Strategies for Xylitol Purification and Crystallization: A Review, Separation Science and Technology, 50:14, 2087-2098, DOI: 10.1080/01496395.2015.1009115

To link to this article: https://doi.org/10.1080/01496395.2015.1009115

Accepted author version posted online: 27

Feb 2015.

Published online: 24 Aug 2015.

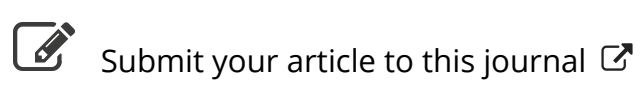

Џll Article views: 682

View Crossmark data ¿

Citing articles: 1 View citing articles $\longleftarrow$ 


\title{
Strategies for Xylitol Purification and Crystallization: A Review
}

\author{
Ernesto A. Martínez, ${ }^{1}$ Eliana V. Canettieri, ${ }^{2}$ José A. C. Bispo, ${ }^{1}$ Marco Giulietti, ${ }^{3}$ João B. de Almeida e \\ Silva, ${ }^{4}$ and Attilio Converti ${ }^{5}$ \\ ${ }^{1}$ Department of Technology, State University of Feira de Santana, UEFS, Feira de Santana, BA, Brazil \\ ${ }^{2}$ Department of Energy, São Paulo State University, UNESP Campus of Guaratinguetá, Guaratinguetá, SP, Brazil \\ ${ }^{3}$ Department of Chemical Engineering, Federal University of São Carlos, São Carlos, SP, Brazil \\ ${ }^{4}$ Department of Biotechnology, Engineering College of Lorena, University of São Paulo, Lorena, SP, Brazil \\ ${ }^{5}$ Department of Civil, Chemical and Environmental Engineering, Genoa University, Genoa, Italy
}

\begin{abstract}
This paper reviews the literature on the main aspects of purification and crystallization of xylitol produced either by chemical or biotechnological routes. Different strategies have been used to clarify media containing xylitol: activated charcoal, $\mathrm{pH}$ adjustment, ion-exchange resins, membrane separation, chromatographic methods, liquid-liquid extraction, and precipitation, or a combination of these techniques. This study explores the most recent results of research work carried out in this field as well as the main approaches to recover and crystallize xylitol in a pure form. The effects of impurities, temperature, supersaturation, crystal seed amount, and size on xylitol crystal growth are also discussed.
\end{abstract}

Keywords xylitol; chemical production; biotechnological production; purification; crystallization

\section{INTRODUCTION}

Xylitol $\left(\mathrm{CH}_{2} \mathrm{OH}-\mathrm{CHOH}-\mathrm{HOCH}-\mathrm{CHOH}-\mathrm{HCOH}-\mathrm{CH}_{2} \mathrm{OH}\right)$ is a particular type of sugar alcohol, or polyol, which is used in food and pharmaceutical industries as a sucrose substitute for people affected by diabetes and obesity, to prevent ear infections in young children, and to reduce gingivitis, and control halitosis (1-3). It can be produced by chemical or biotechnological techniques using pure xylose or xylose-containing hemicellulosic hydrolyzates (4). Figure 1 shows a flow chart of processes employed for xylitol production either using chemical or biotechnological techniques.

Works dealing with obtaining and detoxification of hemicellulosic hydrolyzates as well as xylose-to xylitol bioconversion by fermentation were already reviewed (4-6), while Aliakbarian and co-workers (7) have recently provided an overview of xylitol recovery methods such as chromatographic techniques,

Received 28 May 2014; accepted 14 January 2015.

Address correspondence to Ernesto A. Martínez, Department of Technology, State University of Feira de Santana, UEFS, Av. Transnordestina, s/n, Novo Horizonte, CP 252/294, CEP 44036-900, Feira de Santana, BA, Brazil. E-mail: ernesto.amartinez@yahoo.com.br membrane separation, and crystallization applied either to xylitol solutions obtained by chemical means or to fermented media.

Based on this background, after a brief presentation of xylitol physical and chemical properties, this paper reports an updated literature review of crystallization processes for xylitol recovery from solutions obtained by both ways, and a final discussion of future prospects.

\section{PHYSICAL AND CHEMICAL PROPERTIES OF XYLITOL}

Storing xylitol syrup in an icebox for a long period, Wolfrom and Kohn (8) were the first researchers who prepared crystalline xylitol in a metastable, hygroscopic, monoclinic form, with a melting point (MP) of $61-61.5^{\circ} \mathrm{C}$. Recrystallization either using methanol or ethanol yielded stable colorless orthorhombic crystals with MP of $93-94.5^{\circ} \mathrm{C}$ (9), while Kim and Jeffrey (10) obtained two different orthorhombic morphologies $\left(\mathrm{MP}=92-94^{\circ} \mathrm{C}\right)$, i.e., elongated needles from tetrahydrofuran or well-developed prisms from ethanol. An approximate melting heat of $38 \mathrm{kJmol}^{-1}$ was reported by several authors (11-13), with the lowest $\left(36.1 \mathrm{kJmol}^{-1}\right)$ and highest $\left(39 \mathrm{kJmol}^{-1}\right)$ values being reported by Nurmi and co-workers (14) and by Martínez and co-workers (15), respectively, while Carpentier and co-workers (12) and Tong and co-workers (16) reported melting entropy value for xylitol of 102 and $90.12 \mathrm{~J}$ $\mathrm{mol}^{-1} \mathrm{~K}^{-1}$, respectively (Table 1$)$. Tong and co-workers (16) reported the only values of combustion $\left(\Delta_{\mathrm{c}} \mathrm{H}_{\mathrm{m}}^{\circ}=-2463.2 \pm 1.2\right.$ $\left.\mathrm{kJmol}^{-1}\right)$ and formation $\left(\Delta_{\mathrm{f}} \mathrm{H}_{\mathrm{m}}^{\circ}-1219.3 \pm 0.3 \mathrm{kJmol}-1\right)$ standards molar enthalpy at $25^{\circ} \mathrm{C}$. In addition, these authors reported a solid-liquid phase transition in the temperature range from 87 to $102^{\circ} \mathrm{C}$ with a peak heat capacity $\left(26128 \mathrm{Jmol}^{-1} \mathrm{~K}^{-1}\right)$ at $96^{\circ} \mathrm{C}$.

Xylitol solubility depends on both the temperature and composition of the solvent mixture; solubility in water did in fact decrease from 85 to $50 \mathrm{~g} / 100 \mathrm{~g}$ of solution when temperature was reduced from 60 to $0^{\circ} \mathrm{C}$ ( 333 to $273 \mathrm{~K}$ ), and from 85 to $20 \mathrm{~g} / 100$ $\mathrm{g}$ of solution at $60^{\circ} \mathrm{C}(333 \mathrm{~K})$ when ethanol concentration in the solvent mixture was increased from 0 to $95.3 \%$ (17). Similarly, all the refractive index, density, and viscosity decreased as 


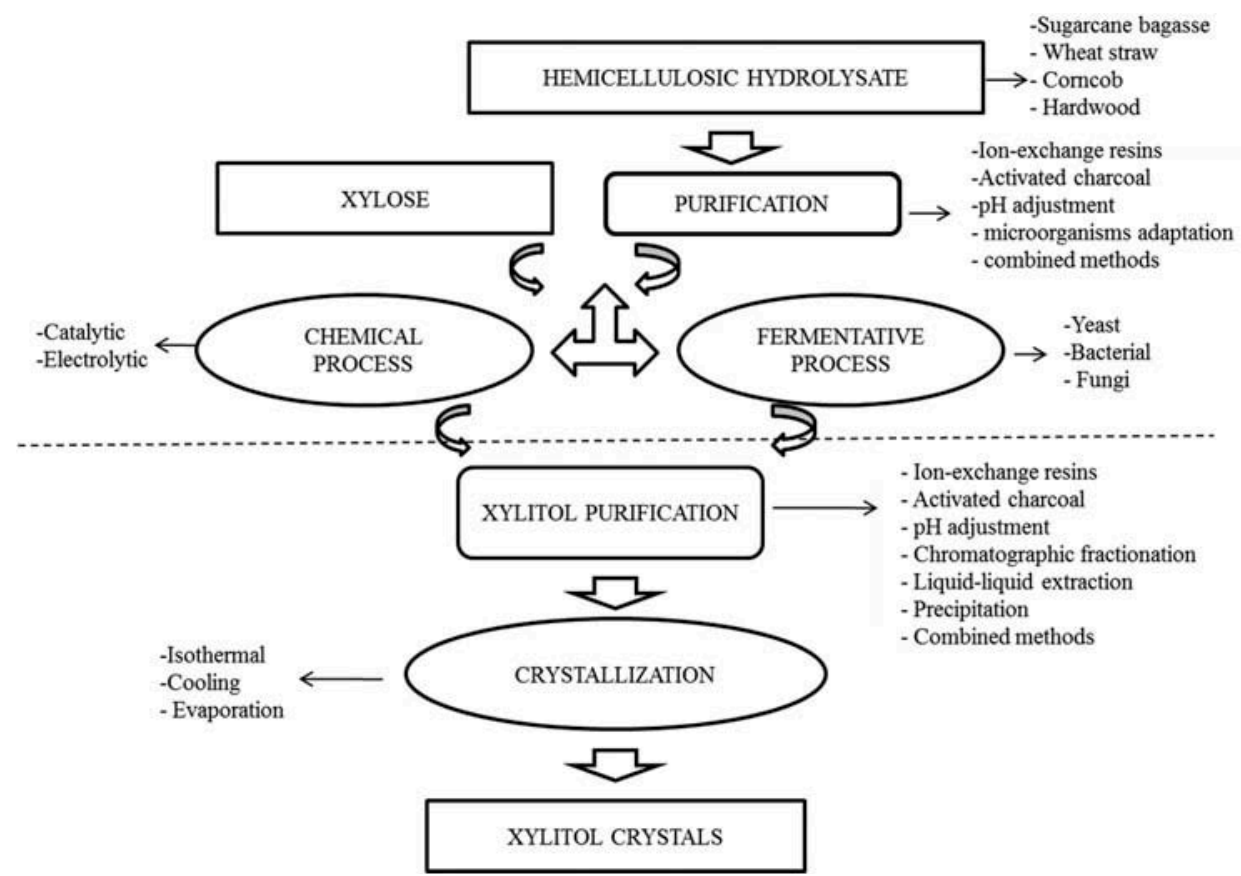

FIG. 1. Flow chart of processes employed for xylitol production either using chemical or biotechnological techniques.

TABLE 1

Thermal characteristics reported for melting of xylitol crystalline powders

\begin{tabular}{|c|c|c|c|}
\hline $\operatorname{Tm}\left({ }^{\circ} \mathrm{C}\right)$ & $\Delta \mathrm{Hm}\left(\mathrm{kJ} \mathrm{mol}^{-1}\right)$ & $\Delta \mathrm{Sm}\left(\mathrm{J} \mathrm{mol}^{-1} \mathrm{~K}^{-1}\right)$ & References \\
\hline $\begin{array}{l}\text { 61.0-61.5 (metastable) } \\
\text { 93.0-94.5 (stable) }\end{array}$ & ND & ND & $\begin{array}{l}\text { Wolfrom and Kohn (8); } \\
\text { Carson and co-workers (9) }\end{array}$ \\
\hline $92-94$ & ND & ND & Kim and Jeffrey (10) \\
\hline $93-94$ & 38.00 & ND & Reamy and Scheweizer (11) \\
\hline 93.70 & 36.10 & ND & Nurmi and co-workers (14) \\
\hline 94.84 & 37.70 & 102.00 & Carpentier and co-workers (12) \\
\hline 96.07 & $33.26 \pm 0.17$ & $90.12 \pm 0.45$ & Tong and co-workers (16) \\
\hline 93.60 & 39.49 & ND & Martínez and co-workers (15) \\
\hline 91.6-92.3 (different additives) & $\begin{array}{l}37.42-38.18 \pm 0.76 \\
\text { (different additives) }\end{array}$ & ND & Seppälä and co-workers (13) \\
\hline
\end{tabular}

$* \mathrm{Tm}=$ melting temperature; $\Delta \mathrm{Hm}=$ melting heat; $\Delta \mathrm{Sm}=$ melting entropy. $\mathrm{ND}=$ not determined.

ethanol concentration increased from 0 to $95.3 \mathrm{~g} / 100 \mathrm{~g}$ and saturation temperature decreased from 60 to $0^{\circ} \mathrm{C}$.

\section{CRYSTALLIZATION OF XYLITOL PRODUCED BY CHEMICAL ROUTES}

Crystallization is widely used for xylitol recovery because it allows obtaining such a polyol in a pure form and solid consistency from relatively impure solutions by a single step. In energy terms, crystallization requires less energy than distillation or other commonly used purification methods.
Very soluble compounds like xylitol can be crystallized by many different alternative methods, among which are solvent evaporation that increases concentration, cooling that decreases solubility $(18,19)$, precipitation, or salting-out, whose choice is suggested by solubility and saturation patterns versus temperature. First, there is a metastable zone where excess solute at the equilibrium concentration is deposited on existing crystals, but no new crystal nucleus is formed. Secondly, there is an intermediate zone where both old and new crystals grow, and nucleation occurs simultaneously. Finally, there is a labile zone where nuclei are formed spontaneously from a clear solution. These three zones are controlled not only by equilibrium, but 
also by process parameters like agitation, temperature, solution purity, and cooling rate.

In order to produce pure crystalline solids in an efficient way, the cooling rate must be controlled so as to obtain a supersaturated solution and maintain it inside the metastable zone, thus minimizing the formation of new crystals (20), and to control the appearance of the crystal nuclei and crystal growth (21).

Treatment of birch wood hydrolyzate containing in $100 \mathrm{~g}$ of solution: $73.0 \mathrm{~g}$. xylose, $6.1 \mathrm{~g}$. arabinose, $9.0 \mathrm{~g}$ mannose, $5.1 \mathrm{~g}$ galactose, and $6.8 \mathrm{~g}$ glucose, using Raney-nickel as a catalyst at $135^{\circ} \mathrm{C}$ and $40 \mathrm{~atm}$ of hydrogen pressure for $2.5 \mathrm{~h}$, allowed for hydrogenation of xylose and other carbohydrates to their respective polyols, and approximately $60 \%$ of the original xylan material was recovered as xylitol (22). Subsequent crystallization and separation of the uncrystallized fraction by liquid chromatography in a cross-linked sulfonated polystyrene cation exchange resin, allowed obtaining eluted fractions containing 0.1-1.95 g arabitol, 0.45-1.70 g mannitol, 0.1-1.0 g galactitol, $0.2-0.85 \mathrm{~g}$ sorbitol, and 0.85-14.3 g xylitol. The fractions with very high xylitol concentrations were recrystallized, and xylitol was recovered with a maximum yield of $60 \%$ and purity higher than $99.5 \%$. Munir and Schiweck (23) proposed the use of a highly acidic, weakly cross-linked divinylbenzene cation exchange resin in calcium form to separate xylitol from centrifuged mother liquor. According to their patent, xylitol readily crystallized and was easily separated with a wire basket, allowing for the recovery of more than $34 \%$ of xylitol present in the original mother liquor.

Vourinen (24) patented a three steps-chemical production of xylitol from D-glucose, and mixtures of D-glucose with D-fructose or D-galactose. D-glucose (1050 g) underwent preliminary oxidative cleavage with pressurized oxygen in autoclave at $85^{\circ} \mathrm{C}$ with an aqueous solution containing sodium hydroxide (18 g), water (264 g), methanol (100 g), and sodium arabinonate $(16 \mathrm{~g})$. After a conversion degree of $98 \%$ glucose, formed sodium arabinonate crystals (741 g) were recovered by centrifugation, dissolved in water, and passed through an acid cation exchange resin. The resulting arabinonic acid was transformed into $\gamma$ lactone by concentrating in vacuum the solution when butanol is added and crystallized to successively give crystals of D-arabino-1,4-lactone, which was then reduced to arabinitol by a ruthenium-on-carbon catalyst with a $90 \%$ molar yield. After crystallization, a second reaction of hydrogenation allowed the arabinitol crystals to be converted to xylitol $(90 \%$ molar yield) using the same catalyst. However, the procedure appears to be too costly for large-scale production.

Xylitol crystallization yield and crystal purity using synthetic media in the main studies published since 1990 are reported in Table 2.

Because crystallization of xylitol from saturated solutions is moisture sensitive, chewing gum processing, in which xylitol is routinely used as a sweetener, is difficult to manage. DuRoss (25) used moisture-resistant melt-crystallized xylitol to produce an agglomerated crystal structure with $99.5 \%(\mathrm{w} / \mathrm{w})$ xylitol. For this purpose, a $70 \mathrm{~g}$ xylitol/100 g solution was heated to $170^{\circ} \mathrm{C}$, cooled to $90^{\circ} \mathrm{C}$ under agitation, seeded with $1 \mathrm{~g}$ of xylitol crystals, mixed until a noticeable increase in viscosity due to crystal formation (50\%) and allowed to crystallize on a tray in the dark.

Attempts were also made to prepare xylitol from xylan-containing material by hydrolyzing it to a mixture of monosaccharides, including xylose, which was then reduced to xylitol using catalysts. For instance, Heikkilä and co-workers (26) reported xylitol crystallization from solutions containing $97 \mathrm{~g}(11.4 \mathrm{~g} / 100 \mathrm{~g}), 170 \mathrm{~g}(19.5 \mathrm{~g} / 100 \mathrm{~g})$, and $185 \mathrm{~g}(20.9 \mathrm{~g} / 100 \mathrm{~g})$ of xylitol, which were previously prepared by hydrogenation of a material containing per 100 $\mathrm{g}$ of solution: $94.2 \mathrm{~g}$ xylonic acid and $1.1 \mathrm{~g}$ xylose using $\mathrm{Ru} /$ carbon $\left(110^{\circ} \mathrm{C}, 13,000 \mathrm{kPa}\right.$ for $\left.3 \mathrm{~h}\right)$, Raney nickel $\left(122^{\circ} \mathrm{C}\right.$, $6,500 \mathrm{kPa}$ for $18 \mathrm{~h})$, and $\mathrm{Rh} / 2 \% \mathrm{Mo} / \mathrm{Al}_{2} \mathrm{O}_{3}\left(140^{\circ} \mathrm{C}, 6,500\right.$ $\mathrm{kPa}$ for $18 \mathrm{~h}$ ), respectively. After concentration and cooling, feed solutions containing 91.3-92.2 g/100 g solution were submitted to a $3^{\circ} \mathrm{C}$ temperature increase, centrifugation, seeding with $0.05-0.06 \mathrm{~g}$ xylitol crystals at $56.5-60^{\circ} \mathrm{C}$ and cooling to $30^{\circ} \mathrm{C}$ for $49-69 \mathrm{~h}$, hence obtaining xylitol purity of the mass among 56.5 and $77 \%$. After separation a yield of dried crystals among 30 and $55 \mathrm{~g}$, and crystal purity among 68 and $93.3 \%$ were obtained.

Fernandez and co-workers (27), investigating xylitol crystallization from hydro-alcoholic solutions containing arabitol and adonitol, observed that the presence of these conformational isomers in small amounts neither affected xylitol solubility $(0.5$ to $0.45 \mathrm{~kg}$ xylitol kg${ }^{-1}$ of solvent) in $25-75 \%(\mathrm{w} / \mathrm{w})$ water/ ethanol solution in the temperature range $10-30^{\circ} \mathrm{C}$ nor enhanced agglomeration. On the other hand, the growth rate of xylitol crystals after addition of adonitol to the system was lower than with arabitol, and this effect was intensified by an increase in the content of the admixtures and somewhat reduced by a temperature raise.

Xylitol can also be crystallized effectively from high viscosity solutions by nucleation when sugars and sugar alcohols such as mannose, xylose, xylitol, mannitol, lactose, lactitol, sucrose, glucose, and fructose are present, and there is high xylitol super saturation. Nurmi and co-workers (28) reported that effective stirring enhances nucleation, enabling it to occur spontaneously, preventing solidification of a crystallization mass and allowing nuclei to develop crystal shapes and to grow until crystal growth is blocked, when the highest yields are found. Samples containing 93.8-94.4 g of xylitol in $100 \mathrm{~g}$ of solution were seeded with $10 \mathrm{~g}$ ground xylitol and cooled from $50-56^{\circ} \mathrm{C}$ to $25-20.5^{\circ} \mathrm{C}$ at different rates $\left(0.042-0.019^{\circ} \mathrm{C}\right.$ $\mathrm{min}^{-1}$ ), thus obtaining crystallization masses with 3.0-3.6 supersaturation, whose viscosity (59.5-198 Pa.s) after vigorous stirring was shown to increase as supersaturation level increased and temperature decreased. Final xylitol separation by a pressure filter ensured xylitol yields in the range of $57-68 \%$. 
TABLE 2

Xylitol crystallization yield and crystal purity from synthetic media

\begin{tabular}{|c|c|c|c|}
\hline Starting material & Conditions & Results & References \\
\hline Melt-crystallized xylitol & $\begin{array}{l}70 \% \text { xyl solution, heated to } 170^{\circ} \mathrm{C} \\
\text { and cooled to } 90^{\circ} \mathrm{C} \text { under } \\
\text { agitation in water bath }\left(80^{\circ} \mathrm{C}\right) \text {. } \\
\text { Seeded with } 1 \mathrm{~g} \text { of xyl crystal. }\end{array}$ & $\begin{array}{l}\text { Agglomerated crystal structure } \\
\text { with } 99.5 \%(\mathrm{w} / \mathrm{w})\end{array}$ & DuRoss (25) \\
\hline \multirow[t]{3}{*}{ Xylan-containing material } & $\begin{array}{l}91.4 \% \text { xyl; } 0.06 \mathrm{~g} \text { xyl crystals as } \\
\text { seed at } 60{ }^{\circ} \mathrm{C} ; \mathrm{CR}=0.010^{\circ} \mathrm{C} \\
\min ^{-1}\end{array}$ & $\begin{array}{l}77.0 \% \text { xyl purity, } 30.72 \% \text { xyl yield } \\
\text { and } 81.2 \% \text { crystal purity }\end{array}$ & $\begin{array}{l}\text { Heikkilä and } \\
\text { co-workers (26) }\end{array}$ \\
\hline & $\begin{array}{l}91.4 \% \text { xyl; } 0.05 \mathrm{~g} \text { xyl crystals as } \\
\text { seed at } 60{ }^{\circ} \mathrm{C} ; \mathrm{CR}=0.012^{\circ} \mathrm{C} \\
\min ^{-1}\end{array}$ & $\begin{array}{l}64.3 \% \text { xyl purity, } 31.74 \% \text { xyl yield } \\
\text { and } 93.3 \% \text { crystal purity }\end{array}$ & \\
\hline & $\begin{array}{l}92.2 \% \text { solution, } 0.05 \mathrm{~g} \text { xyl crystals } \\
\text { as seed at } 60^{\circ} \mathrm{C} ; \mathrm{CR}=0.007^{\circ} \mathrm{C} \\
\min ^{-1}\end{array}$ & $\begin{array}{l}56.5 \% \text { xyl (purity), } 29.73 \% \text { xyl } \\
\text { yield and } 68 \% \text { xyl purity }\end{array}$ & \\
\hline $\begin{array}{l}\text { Hydroalcoholic solutions } \\
\text { containing xylitol, arabitol, and } \\
\text { adonitol }\end{array}$ & $\begin{array}{l}0.5 \text { to } 0.45 \mathrm{~kg} \text { xyl } / \mathrm{kg} \text { of solvent, } \\
25 / 75 \% \text { water } / \text { ethanol mixture } \\
\text { from } 10.86 \text { to } 29.86^{\circ} \mathrm{C}\end{array}$ & $\begin{array}{l}\text { Agglomeration phenomenon not } \\
\text { enhanced; more pronounced } \\
\text { reduction of xyl growth rate }\end{array}$ & $\begin{array}{l}\text { Fernandez and } \\
\text { co-workers }(27)\end{array}$ \\
\hline \multirow[t]{3}{*}{$\begin{array}{l}\text { Solution containing sugars and } \\
\text { sugar alcohols such as mannose, } \\
\text { xylose, mannitol, lactose, } \\
\text { lactitol, sucrose, glucose, } \\
\text { fructose }\end{array}$} & $\begin{array}{l}12.3 \mathrm{~kg} \text { of the } \mathrm{CM}, 93.8 \mathrm{~g} \text { of } \mathrm{xyl} / \\
100 \mathrm{~g} \text { solution, } 10 \mathrm{~g} \text { ground } \mathrm{xyl} \\
\text { as seed, } 50{ }^{\circ} \mathrm{C}, \mathrm{CR}=0.042^{\circ} \mathrm{C} \\
\min ^{-1}\end{array}$ & $67.0 \%$ xyl yield & $\begin{array}{l}\text { Nurmi and } \\
\text { co-workers (28) }\end{array}$ \\
\hline & $\begin{array}{l}13.58 \mathrm{~kg} \text { of the } \mathrm{CM}, 94.1 \mathrm{~g} \text { of } \mathrm{xyl} / \\
100 \mathrm{~g} \text { solution, } 10 \mathrm{~g} \text { ground } \mathrm{xyl} \\
\text { as seed, } 50^{\circ} \mathrm{C}, \mathrm{CR}=0.030^{\circ} \mathrm{C} \\
\min ^{-1}\end{array}$ & $57.0 \%$ xyl yield & \\
\hline & $\begin{array}{l}13.52 \mathrm{~kg} \text { of the crystallization mass } \\
\text { containing } 94.4 \mathrm{~g} \text { of xyl } / 100 \mathrm{~g} \\
\text { solution, } 10 \mathrm{~g} \text { ground xyl as } \\
\text { seed, } 56^{\circ} \mathrm{C}, \mathrm{CR}=0.019^{\circ} \mathrm{C} \min ^{-1}\end{array}$ & $68.0 \%$ xyl yield & \\
\hline Synthetic solutions & $\begin{array}{l}65.6 \%(\mathrm{w} / \mathrm{w}) \text { xyl solution; purity } \\
\text { over } 99 \% \text { d.s.; } 27.4 \mathrm{~kg} / \mathrm{h} ; 64 \pm 2^{\circ} \\
\text { C; from } 140 \text { to } 150 \mathrm{bar} ; \\
\text { particulate xyl. suspended in a } \\
\text { gas (spray nozzle at } 60 \mathrm{~kg} / \mathrm{h} \text { at } \\
\left.104-107^{\circ} \mathrm{C}\right) ; 4 \text { min } \\
66.6 \text { and } 72 \% \text { xyl solution and } 55 \\
60 \text { and } 70 \text { bar of feed pressure }\end{array}$ & $\begin{array}{l}\text { Microcrystals with } 0.1 \% \text { moisture } \\
\text { and conditioning it into an } \\
\text { agglomerated product ( } 1 \text { to } \\
2 \mathrm{~cm} \text { ) }\end{array}$ & $\begin{array}{l}\text { Heikkilä and } \\
\text { co-workers (29) }\end{array}$ \\
\hline Water/ethanol solutions & $\begin{array}{l}\text { Isothermal conditions at } 5,25 \text { and } \\
40^{\circ} \mathrm{C}\end{array}$ & $\begin{array}{l}\text { Xyl crystallization was } 11 \text { times } \\
\text { faster in } 90 \% \text { ethanol that in } \\
60 \% \text { ethanol at } 25^{\circ} \mathrm{C} \text {; the rate of } \\
\text { xyl nucleation increased } 7 \text { times } \\
\text { at } 5^{\circ} \mathrm{C} \text { with } 60 \% \text { ethanol and } 30 \\
\text { times at } 40^{\circ} \mathrm{C} \text { with } 90 \% \text { ethanol }\end{array}$ & Vyglazov (30) \\
\hline Synthetic solutions & $\begin{array}{l}728 \mathrm{~g} / \mathrm{l} \text { xyl concentration; }-6.0^{\circ} \mathrm{C} \\
\text { crystallization temperature }\end{array}$ & $\begin{array}{l}54 \% \text { crystal yield; } 97.0 \% \text { xyl } \\
\text { purity }\end{array}$ & $\begin{array}{l}\text { De Faveri and } \\
\text { co-workers (32) }\end{array}$ \\
\hline Water/methanol solutions & $\begin{array}{l}0-66.7 \% \text { methanol content and } \\
\text { temperature from } 20-55^{\circ} \mathrm{C}\end{array}$ & $\begin{array}{l}0.02 \text { to } 5.10^{-9} \mathrm{~m} . \mathrm{s}^{-1} \text { growth rates } \\
\text { and } 0.01 \text { to } 9.7 .10^{9} \mathrm{~m}^{-3} \mathrm{~s}^{-1} \\
\text { nucleation rates }\end{array}$ & $\begin{array}{l}\text { Hao and } \\
\text { co-workers (31) }\end{array}$ \\
\hline
\end{tabular}


TABLE 2

(Continued)

\begin{tabular}{|c|c|c|c|}
\hline Starting material & Conditions & Results & References \\
\hline Hydroalcoholic solution & $\begin{array}{l}40,50 \text { and } 60^{\circ} \mathrm{C} \text { saturation } \\
\text { temperature and } \mathrm{CR}=0.10 \text {, } \\
0.25,0.50^{\circ} \mathrm{C} \mathrm{m^{-1 }}\end{array}$ & $\begin{array}{l}\mathrm{g}=2.44 ; \mathrm{n}=2.44 ; \mathrm{m}=3.44 \\
\mathrm{~B}_{\mathrm{N}}=4.76 .10^{-18} \mathrm{~kg} \mathrm{~kg}^{-1} \text { of } \\
\text { solvent }\end{array}$ & $\begin{array}{l}\text { Martínez and } \\
\text { co-workers (36) }\end{array}$ \\
\hline Synthetic solutions & Effect of additives & $\begin{array}{l}7.3 \pm 0.4 \mathrm{~mm} \mathrm{~h}^{-1} \text { crystallization } \\
\text { front speed, } 22^{\circ} \mathrm{C} \text {, methanol; } \\
\text { speeds } 33 \text { times higher in } \\
\text { vertical tubes and } 170 \text { times } \\
\text { higher in horizontal tubes than } \\
\text { with pure xyl }(0.7 \pm 0.1 \mathrm{~mm} / \mathrm{h}) \text {. }\end{array}$ & $\begin{array}{l}\text { Seppälä and } \\
\text { co-workers (13) }\end{array}$ \\
\hline
\end{tabular}

${ }^{*} \mathrm{CR}=$ cooling rate; $\mathrm{xyl}=$ xylitol; $\mathrm{CM}=$ crystallization mass; $\mathrm{g}=$ order of crystal growth kinetics; $\mathrm{n}=$ order of nucleation kinetics; $\mathrm{m}=$ apparent order of nucleation kinetics; $\mathrm{B}_{\mathrm{N}}=$ system kinetic constant.

Heikkilä and co-workers (29) crystallized xylitol with purity over $99 \%$ d.s. from a $65.6 \%(\mathrm{w} / \mathrm{w})$ xylitol solution $(2 \mathrm{~kg})$ supplied by a spray nozzle at a rate of $27.4 \mathrm{~kg} \mathrm{~h}^{-1}$, temperature of $64 \pm 2^{\circ} \mathrm{C}$ and feed pressure in the range 140-150 bar. Small particles of dried product were fed into the microcrystallization equipment at a rate of $60 \mathrm{~kg} \mathrm{~h}^{-1}$ for $4 \mathrm{~min}$, while air temperature was maintained at $104-107^{\circ} \mathrm{C}$. An agglomerated or porous powder xylitol layer about $1-2 \mathrm{~cm}$ thick formed on the screen, where it was left for $60 \mathrm{~min}$, while temperature was reduced from 62 to $45^{\circ} \mathrm{C}$, and the resulting xylitol microcrystals $(2.6 \mathrm{~kg})$ with $0.1 \%$ moisture content were collected, milled, and sieved. When the same protocol was applied varying xylitol concentration $(65.6-72 \mathrm{~g} / 100 \mathrm{~g}$ solution), temperature $\left(64-65^{\circ} \mathrm{C}\right)$, feed pressure $(55-70 \mathrm{bar})$, and air drying temperature $\left(101-108^{\circ} \mathrm{C}\right)$ xylitol microcrystals moisture content ranged from 0.1 to $1.8 \%$.

To accelerate crystallization, several additives were tested as seeds $(15,19)$ using different organic solvents such as methanol, acetone, ethanol, methanol-water, and ethanol-water mixtures $(13,15,30,31)$, and their effects on latent heat, melting temperature, and long-term durability of the supercooled state assessed $(13,15)$.

For instance, Vyglazov (30) investigated the kinetics of xylitol crystallization from ethanol/water solutions as function of the degree of supersaturation of the initial solution under isothermal conditions in the temperature range $5-40^{\circ} \mathrm{C}$. An increase in ethanol concentration from 60 to $90 \%(\mathrm{v} / \mathrm{v})$ accelerated xylitol crystallization by a factor of 11 at $25^{\circ} \mathrm{C}$, while a simultaneous increase in temperature from 5 to $40^{\circ} \mathrm{C}$ led to a 7-10-fold increase in the rate of xylitol nucleation, especially at liquid-to-solid ratios greater than 3 . Changes in the structure of the mixed solvent likely hindered the diffusion of xylitol molecules to the surface of growing crystals, thus limiting xylitol crystallization. As xylitol crystallization rate at $90 \%(\mathrm{v} / \mathrm{v})$ ethanol concentration was only thrice that at $60 \%(\mathrm{v} / \mathrm{v})$, it is likely that crystal size depends on ethanol concentration and temperature, with larger crystals formed at lower ethanol levels.
By a $3^{2}$ full-factorial design combined with response surface methodology, De Faveri and co-workers (32) found that an initial xylitol supersaturation value of $728 \mathrm{~g} \mathrm{l}^{-1}$ in synthetic solutions and cooling temperature of $-6.0^{\circ} \mathrm{C}$ were the operating conditions under which xylitol purity (97\%) and crystallization yield $(54 \%)$ were simultaneously optimized. However, purity close to $100 \%$, which is needed to meet industrial standards, was predicted for conditions $\left(583 \mathrm{~g} \mathrm{l}^{-1}\right.$ and $\left.-2.4^{\circ} \mathrm{C}\right)$ leading to unsatisfactory crystallization yield $(25 \%)$. As suggested by the use in the industrial crystallization practice of supersaturation levels in the range 1.12-1.40, a non-excessive value of this parameter is needed to make the control of crystallization easier (33).

The traditional approach to the optimization problem using the one variable-at-a-time method (34) is the most common one in xylitol crystallization literature. Hao and co-workers (31) determined the solubility and crystallization kinetics of xylitol in a methanol/water system. In general, xylitol solubility, crystal growth, and nucleation rate decreased with increasing methanol content, likely due to a decrease in the collision probability of xylitol molecules in solution, while they increased with temperature. These authors reported growth and nucleation rates in the ranges $0.02-5 \times 10^{-9} \mathrm{~m} . \mathrm{s}^{-1}$ and $0.01-9.7 \times 10^{9} \mathrm{~m}^{-3} \mathrm{~s}^{-1}$, while scanning electron microscopy revealed that the final shape of xylitol crystals was rounded and that there was negligible breakage and agglomeration. Based on the theory of population balance, xylitol nucleation and growth rates in methanol/water solutions were assessed using batch data for xylitol crystallization and the nonlinear least-squares method. At constant temperature, the nucleation and growth rate of xylitol decreased with the increase in methanol content.

Liavoga and co-workers (35) obtained xylitol with 95\% purity and $10 \%$ yield from wheat straw acid hydrolyzate after reduction with sodium borohydride followed by fractional crystallization. The mixture of four alditols (xylitol, L-arabitol, D-sorbitol, and galactitol) was purified by open-column 
chromatography using a strongly basic anion-exchange resin obtaining 7\% xylitol crystals with $99 \%$ purity.

Martínez and co-workers (36) studied the combined effects of saturation temperature $\left(40,50\right.$ and $\left.60^{\circ} \mathrm{C}\right)$ and cooling rate $(0.10$, 0.25 , and $0.50^{\circ} \mathrm{C} \mathrm{min}^{-1}$ ) on kinetics of commercial xylitol crystallization in an ethanol/water $(50: 50 \% \mathrm{w} / \mathrm{w})$ solution according to the Nývlt and co-workers (20) method. Crystallization occurred very quickly (900 to $16,440 \mathrm{~s}$ ), and an increase in the cooling rate from 0.10 to $0.50^{\circ} \mathrm{C} \mathrm{min}^{-1}$ led to a higher supersaturation state and decreased the nucleation temperature by 9,8 and $3^{\circ} \mathrm{C}$. On the other hand, the maximum solution undercooling increased by 9,7 and $3^{\circ} \mathrm{C}$ for saturation temperatures of 40,50 , and $60^{\circ} \mathrm{C}$. The best correlation between nucleation and growth rates (in log terms) was obtained when the value of the mass concentration exponent (c) in secondary nucleation kinetics of the solids concentration was 0 . The nucleation model explained $73 \%$ of the total variation in the response as a function of the apparent growth rate, and the regression constant or intercept was 14.88. Estimated kinetic parameters such as orders of growth $(\mathrm{g}=2.44)$ and nucleation kinetics $(\mathrm{n}=$ $2.44)$, apparent order of nucleation kinetics $(\mathrm{m}=3.44)$, and system kinetic constant $\left(\mathrm{B}_{\mathrm{N}}=4.76 \times 10^{-18} \mathrm{~kg} \mathrm{~kg}_{\text {solv }}{ }^{-1}\right)$ and the mean crystal size calculated were satisfactorily compared with the experimental one (11.3\% mean deviation).

Seppälä and co-workers (13) reported the effect of different additives on the speed of xylitol crystallization front at various supercooling levels. At $22^{\circ} \mathrm{C}$, this speed $\left(7.3 \pm 0.4 \mathrm{~mm} \mathrm{~h}^{-1}\right)$ was about 33 times higher than that of pure xylitol $(0.7 \pm$ $0.1 \mathrm{~mm} \mathrm{~h}^{-1}$ ) in vertical tubes and 170 times higher in horizontal tubes. Methanol was the best additive, whose effect was mainly the result of flow currents generated by its separation during crystallization.

Cheng and co-workers (37) studied xylitol crystallization by seeding a solution containing $800 \mathrm{~g} \mathrm{l}^{-1}$ at $65^{\circ} \mathrm{C}$ and cooling the solution at a rate of $1^{\circ} \mathrm{C} \min ^{-1}$ up to $15^{\circ} \mathrm{C}$ with periodic mixing. After separation of xylitol crystals by centrifugation, the mother liquor was further concentrated to $800 \mathrm{~g} \mathrm{l}^{-1}$ by rotary vacuum evaporation at $65^{\circ} \mathrm{C}$ and then subject to recrystallization under the same conditions, giving xylitol crystals with $99.5 \%$ purity.

\section{CRYSTALLIZATION OF XYLITOL OBTAINED BY BIOTECHNOLOGICAL TECHNIQUES}

Biotechnological techniques depend on the quality of the desired product along with the composition of the fermented liquor, which contains yeast, yeast debris, and other contaminants such as ingredients of the cultivation medium, residual substrates, and fermentation by-products. The fermented broth is centrifuged to remove biomass and concentrated in order to increase xylitol concentration (38). Xylitol characteristics such as molecule size and impurities found in fermented broths such as sugar and sugar alcohols, inorganic salts, and polypeptides are critical factors for the selection of a recovery method (19, $39,40-42)$.
Different strategies such as the use of activated charcoal (43 - 46), $\mathrm{pH}$ adjustment (38), ion-exchange resins $(15,37$, $43,47)$, chromatographic methods $(22,23,26,48,49)$, membrane separation (52), liquid-liquid extraction, and precipitation (46), or combined methods $(19,50,51)$ have been successfully used to clarify the media (Table 3 ).

Crystallization of products obtained by fermentation can only be performed after the fermented broth has been purified $(7,15,53)$. Xylitol crystallization has drawn more attention in the past two decades and is believed to be the final step to obtain xylitol in a highly purified form; however, several impurities coming from the hydrolysis of the lignocellulosic matrix or nutrients added for medium preparation are recognized as prejudicial to the formation of xylitol crystals (7). Owing to the complexity of the fermentation broth, the purity of xylitol obtained by direct crystallization is not acceptable; therefore, the fermented broth must be purified prior to crystallization to produce pure xylitol crystals $(19,54)$.

Xylitol crystallization yield and crystal purity from xylitolrich solutions obtained by biotechnological techniques are summarized on Table 4.

Heikkilä and co-workers $(48,49)$ patented a simple method to produce xylitol from hemicellulosic hydrolyzates that makes use of Debaryomyces hansenii and Candida tropicalis to convert xylose to xylitol and most hexoses to ethanol. The xylitolrich solution ( $86.5 \mathrm{~g} / 100 \mathrm{~g}$ solution) was recovered by chromatographic separation from the fermented broth and evaporated at $65^{\circ} \mathrm{C}$ up to $92 \mathrm{~g} / 100 \mathrm{~g}$ solution. Then, $2.2 \mathrm{~kg}$ of the evaporated solution was seeded with $0.03 \%$ xylitol crystals (0.04 $\mathrm{mm}$ size), and the crystallization solution was cooled to $45^{\circ} \mathrm{C}$ for $55 \mathrm{~h}$. After centrifugation ( $5 \mathrm{~min}, 2000 \mathrm{~g}$ ) and water washing, the recovered crystals had a mean size of $0.37 \mathrm{~mm}$ and $99.4 \%$ purity.

The simplest protocols used to recover biotechnologicallyproduced xylitol are obviously those employed in fermented synthetic media, because of the nearly negligible amounts of contaminants. As underlined by Misra and co-workers (46), the treatment with activated charcoal followed by vacuum concentration and crystallization is in fact as a cost effective, easy, and environmentally friendly route for xylitol recovery, providing a sound basis for large scale industrial production and purification of such a highly valuable sugar alcohol.

Investigating xylitol adsorption by charcoal from synthetic broths fermented by $D$. hansenii with xylitol concentration in the range $5-200 \mathrm{~g}^{-1}$, at 25 and $50^{\circ} \mathrm{C}, \mathrm{pH} 6.0$, under magnetic stirring for $1 \mathrm{~h}$, Sampaio and co-workers (44) obtained the best clarification results using $20 \mathrm{~g} \mathrm{l}^{-1}$ activated charcoal at $25^{\circ} \mathrm{C}$, which allowed removing nearly $79 \%$ of colored contaminants, $94 \%$ of amino acids, and $69 \%$ of total proteins, and recovering xylitol almost completely. In an alternative approach using A-505 anionic-exchange and C-504 cationic-exchange resins, Martínez and co-workers (15) were able to recover nearly $85 \%$ of xylitol initially present in the medium. 
TABLE 3

Strategies used for the purification of xylitol (other than crystallization)

\begin{tabular}{|c|c|c|c|c|}
\hline Method & $\begin{array}{l}\text { Fermentation media } \\
\text { and microorganism }\end{array}$ & Best conditions & Results & References \\
\hline \multirow[t]{4}{*}{ Activated charcoal } & $\begin{array}{l}\text { Sugarcane } \\
\text { hemicellulosic } \\
\text { hydrolyzate by } \\
\text { Candida } \\
\text { guilliermondii }\end{array}$ & $\begin{array}{l}25 \mathrm{~g} / 100 \mathrm{ml} \text { solution, } 80^{\circ} \mathrm{C}, 100 \mathrm{rpm}, 1 \mathrm{~h} \text {, } \\
\mathrm{pH} 6.0\end{array}$ & $19.1 \%$ xyl loss & $\begin{array}{l}\text { Gurgel and } \\
\text { co-workers (43) }\end{array}$ \\
\hline & $\begin{array}{l}\text { Synthetic media by } \\
\text { Debaryomyces } \\
\text { hansenii }\end{array}$ & $\begin{array}{l}20 \mathrm{~g} / 1 \text { solution, } 25^{\circ} \mathrm{C} \text {, magnetic agitation, } \\
1 \mathrm{~h}, \mathrm{pH} 6.0\end{array}$ & $\approx 0 \mathrm{xyl}$ loss & $\begin{array}{l}\text { Sampaio and } \\
\text { co-workers (44) }\end{array}$ \\
\hline & $\begin{array}{l}\text { Corn fiber } \\
\text { hydrolyzate by } C \text {. } \\
\text { tropicalis }\end{array}$ & $\begin{array}{l}2.5 \mathrm{~g} / 100 \mathrm{ml} \text { solution, } \mathrm{pH} 6.0,80^{\circ} \mathrm{C}, 1 \mathrm{~h} \text {, } \\
100 \mathrm{rpm}\end{array}$ & $\begin{array}{l}69.0 \% \text { protein } \\
\text { removal }\end{array}$ & Affleck (52) \\
\hline & & & $\begin{array}{l}79.5 \% \text { of the UV } \\
\text { absorbing material } \\
\text { adsorbed about } \\
25-50 \% \text { xyl }\end{array}$ & \\
\hline \multirow[t]{4}{*}{$\begin{array}{l}\text { Ion-exchange } \\
\text { resins }\end{array}$} & Mother liquor & $\begin{array}{l}\text { Weakly cross-linked divinylbenzene } \\
\text { cation-exchange resin in Ca form }\end{array}$ & $\begin{array}{l}\text { More than } 34 \% \text { of } \\
\text { xyl recovered }\end{array}$ & $\begin{array}{l}\text { Munir and } \\
\quad \text { Schiweck, (23) }\end{array}$ \\
\hline & $\begin{array}{l}\text { Sugarcane } \\
\text { hemicellulosic } \\
\text { hydrolyzate by } C \text {. } \\
\text { guilliermondii }\end{array}$ & $\begin{array}{l}\text { Amberlite } 200 \mathrm{C} \text { cation-exchange and } \\
\text { Amberlite } 94 \mathrm{~S} \text { anion-exchange resins }\end{array}$ & $21-57 \%$ xyl loss & $\begin{array}{l}\text { Gurgel and } \\
\text { co-workers (43) }\end{array}$ \\
\hline & $\begin{array}{l}\text { Wheat straw } \\
\text { hemicellulosic } \\
\text { hydrolyzate by } C \text {. } \\
\text { guilliermondii }\end{array}$ & $\begin{array}{l}\text { A-860S strong base anion-exchange and } \\
\text { A-500PS strong base anion-exchange } \\
\text { resins }\end{array}$ & $21.1 \%$ xyl loss & $\begin{array}{l}\text { Canilha and } \\
\text { co-workers (47) }\end{array}$ \\
\hline & $\begin{array}{l}\text { Synthetic media by } \\
\text { C. guilliermondii }\end{array}$ & $\begin{array}{l}\text { A-505 anion-exchange and C-504 cation- } \\
\text { exchange resins }\end{array}$ & $\begin{array}{l}97.5 \% \text { removal of } \\
\text { soluble } \\
\text { byproducts, } \\
99.5 \% \text { removal of } \\
\text { coloration } \\
\text { medium } 15.23 \% \\
\text { xyl loss }\end{array}$ & $\begin{array}{l}\text { Martínez and } \\
\text { co-workers (19) }\end{array}$ \\
\hline pH adjustment & $\begin{array}{l}\text { Sugarcane } \\
\text { hemicellulosic } \\
\text { hydrolyzate by } C \text {. } \\
\text { guilliermondii }\end{array}$ & pH 7.0 with $\mathrm{NaOH}$ & $\begin{array}{l}26.4 \% \text { removal of } \\
\text { proteins }\end{array}$ & $\begin{array}{l}\text { Martínez and } \\
\text { Santos, (38) }\end{array}$ \\
\hline $\begin{array}{l}\text { Liquid-liquid } \\
\text { extraction }\end{array}$ & $\begin{array}{l}\text { Synthetic xylose and } \\
\text { corn cob } \\
\text { hemicellulosic } \\
\text { hydrolyzate }\end{array}$ & $\begin{array}{l}\text { 1:5 (volume/volume) of fermentation } \\
\text { broth and ethyl acetate }\end{array}$ & $\begin{array}{l}21.72 \mathrm{~g} / 1 \mathrm{xyl} \\
\text { extracted }\end{array}$ & $\begin{array}{l}\text { Misra and } \\
\quad \text { co-workers (46) }\end{array}$ \\
\hline $\begin{array}{l}\text { Membrane } \\
\text { separation }\end{array}$ & $\begin{array}{l}\text { Corn fiber } \\
\text { hydrolyzate by } \\
\text { Candida tropicalis }\end{array}$ & $\begin{array}{l}10,000 \text { nominal molecular weight cutoff } \\
\text { polysulfone membrane }\end{array}$ & $\begin{array}{l}82.2-90.3 \% \text { of xyl } \\
\text { passed through; } \\
\text { purity up to } 90.3 \%\end{array}$ & Affleck (52) \\
\hline Precipitation & $\begin{array}{l}\text { Synthetic xylose and } \\
\text { corn cob } \\
\text { hemicellulosic } \\
\text { hydrolyzate }\end{array}$ & $\begin{array}{l}1: 1 \text { ratio }(\mathrm{v} / \mathrm{v}) \text { fermented broth and } \\
\text { acetone }\end{array}$ & $\begin{array}{l}67.44 \% \text { xyl recovery } \\
\text { in aqueous phase }\end{array}$ & $\begin{array}{l}\text { Misra and } \\
\text { co-workers (46) }\end{array}$ \\
\hline
\end{tabular}


TABLE 3

(Continued)

\begin{tabular}{|c|c|c|c|c|}
\hline Method & $\begin{array}{l}\text { Fermentation media } \\
\text { and microorganism }\end{array}$ & Best conditions & Results & References \\
\hline \multirow[t]{3}{*}{ Combined methods } & $\begin{array}{l}\text { Sugarcane bagasse } \\
\text { by electrolytic } \\
\text { reduction from } \\
\text { xylose to xyl }\end{array}$ & Activated carbon & Xyl granules & $\begin{array}{l}\text { Manalo and } \\
\text { co-workers (50) }\end{array}$ \\
\hline & $\begin{array}{l}\text { Sugarcane } \\
\text { hemicellulosic } \\
\text { hydrolyzate by } C \text {. } \\
\text { guilliermondii }\end{array}$ & $\begin{array}{l}\text { IR } 120 \text { cation-exchange and IRA } 410 \\
\text { anion-exchange resins }\end{array}$ & $\begin{array}{l}60 \% \text { crystallization } \\
\text { yield and } 33 \% \\
\text { total recovery }\end{array}$ & $\begin{array}{l}\text { Mussatto and } \\
\text { co-workers (54) }\end{array}$ \\
\hline & $\begin{array}{l}\text { Sugarcane } \\
\text { hemicellulosic } \\
\text { hydrolyzate by } C \text {. } \\
\text { guilliermondii }\end{array}$ & $\begin{array}{l}\text { The fractions were combined, } 6.5 \text {-fold } \\
\text { concentrated at } 50^{\circ} \mathrm{C} \text {, maintained at } 4^{\circ} \\
\mathrm{C} \text { for } 24 \mathrm{~h} \text { and supplemented with } 400 \\
\text { mg of finely ground standard xyl } \\
\text { pH } 7.0 \text { with NaOHA-505 anion- } \\
\text { exchange, C-504 cation-exchange } \\
\text { resins }\end{array}$ & $8.15 \%$ xyl loss & $\begin{array}{l}\text { Martínez and } \\
\text { co-workers (19) }\end{array}$ \\
\hline
\end{tabular}

${ }^{*} \mathrm{CR}=$ cooling rate; $\mathrm{xyl}=$ xylitol.

Gurgel and co-workers (43) used activated charcoal and ionexchange resins (Amberlite 200C strong cation-exchange resin and Amberlite 94S weak anion-exchange resin) to clarify xylitol-containing sugarcane bagasse hydrolyzate fermented by Candida guilliermondii. Optimal clarification with acceptable xylitol loss (19.1\%) was obtained with $250 \mathrm{~g} \mathrm{l}^{-1}$ activated carbon at $80^{\circ} \mathrm{C}$ and $\mathrm{pH} 6.0$, under agitation at $100 \mathrm{rpm}$ for 1 h. As no xylitol crystal was observed by the naked eye in clarified solution containing $20.15 \mathrm{~g} \mathrm{l}^{-1}$ xylitol, even after filtration and concentration for 5 weeks at $-15^{\circ} \mathrm{C}$, it was seeded with $1 \mathrm{~g} \mathrm{l}^{-1}$ commercial finely ground xylitol, thereby leading, after one week at $-15^{\circ} \mathrm{C}$, to the formation of crystals with uniform color and needle shape. Even lower xylitol loss (8.15\%) was reported by Martínez and co-workers (19) for the treatment of sugarcane hemicellulosic hydrolyzate fermented by $C$. guilliermondii with A-505 anion-exchange and C-504 cation-exchange resins, after $\mathrm{pH}$ adjustment to 7.0 and centrifugation. Martinez and Santos (38), who investigated the effect of $\mathrm{pH}$ (5.0-9.0) on precipitation of impurities from the same medium, observed maximum precipitation rate and proteins removal $(26.4 \%)$ at $\mathrm{pH}$ 7.0. On the other hand, no precipitates were formed from rice bran derived impurities, and protein removal was not influenced by $\mathrm{pH}$ adjustment in the range 5.0-6.0.

Affleck (52) proposed membrane separation as an alternative method for the recovery of xylitol from fermented broth, because it has the potential for energy savings and higher purity. Xylitol produced by $C$. tropicalis from corn fiber hydrolyzate with a xylitol yield factor of $0.6 \mathrm{~g} \mathrm{~g} \mathrm{~g}^{-1}$ of xylose was optimally separated from the impurities with a 10,000 nominal molecular weight cutoff polysulfone membrane, allowing $82.2-90.3 \%$ of xylitol contained in the fermentation broth to pass through, while retaining $49.2-53.6 \%$ of oligopeptides and peptides. Permeate crystallization led to xylitol crystals with purity up to $90.3 \%$. On the other hand, the activated carbon treatment for $1 \mathrm{~h}(2.5 \mathrm{~g}$ per $100 \mathrm{~g}$ of solution, $\mathrm{pH} 6.0,80^{\circ} \mathrm{C}$, and $100 \mathrm{rpm}$ ) was able to more effectively remove colored contaminants (up to 79.5\%), but adsorbed about $25-50 \%$ of xylitol. Taking into account the common inability of membrane treatment to remove impurities, these results confirm that this kind of polysulfone should only be used in a pretreatment for further purification steps in the presence of colored, viscous mother liquors (52).

Rivas and co-workers (45) reported on the purification of xylitol obtained from corn cob hydrolyzates fermented by $D$. hansenii using charcoal at solid-to-liquid ratios varying from $1: 125$ to $1: 5$. According to these authors, the use of $1 \mathrm{~kg}$ of charcoal $/ 15 \mathrm{~kg}$ of liquor resulted in an increase in xylitol content of up to $0.6873 \mathrm{~kg} / \mathrm{kg}$ of nonvolatile components, almost complete decolorization (98.8\% removal of ICUMSA 4 color), $81.9 \%$ removal of proteins, and $66.7 \%$ removal of other nonvolatile compounds, while keeping xylitol loss to an acceptable level (only $3.2 \%$ of the initial amount). To purify and crystallize xylitol from corncob hydrolyzates fermented by C. tropicalis, Wei and co-workers (51) tested a multistep purification protocol consisting of a) decolorization with activated charcoal $\left(1 \%, 60^{\circ} \mathrm{C}, 165 \mathrm{rpm}\right)$, b) desalting with a combination of two ion-exchange resins (732 and D301), c) separation with UBK-555( $\left.\left(\mathrm{Ca}^{2+}\right), \mathrm{d}\right)$ vacuum-concentration of the fermentation broth up to supersaturation ( $750 \mathrm{~g} \mathrm{l}^{-1}$ xylitol), e) seeding with 
TABLE 4

Xylitol crystallization yield and crystal purity from solutions obtained by biotechnological routes

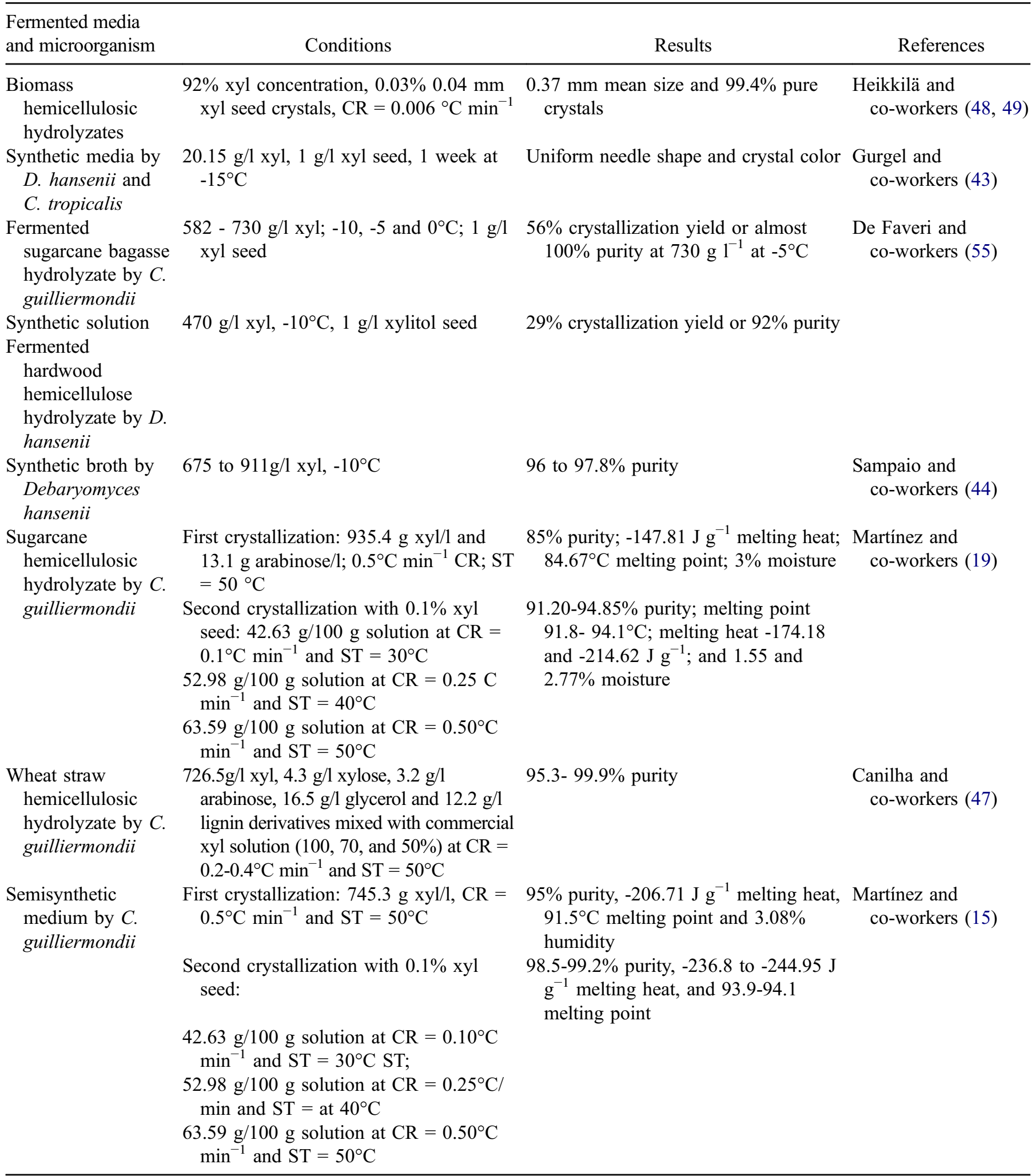

${ }^{*} \mathrm{CR}=$ cooling rate; $\mathrm{ST}=$ saturation temperature; $\mathrm{xyl}=$ xylitol. 
$1 \%$ xylitol crystals, and f) cooling to $-20^{\circ} \mathrm{C}$ for $48 \mathrm{~h}$. Crystalline xylitol with regular tetrahedral shape, $95 \%$ purity, and $60.2 \%$ crystallization yield was obtained.

Misra and co-workers (46) proposed a new multistep protocol for xylitol purification from either synthetic xylose solutions or corn cob hemicellulosic hydrolyzates fermented by adapted $C$. tropicalis cells, which consisted of liquid-liquid extraction with 1:5 (v/v) ethyl acetate $\left(21.72 \mathrm{~g} \mathrm{l}^{-1}\right.$ xylitol extracted), xylitol precipitation (67.44\% recovery yield), activated charcoal treatment, vacuum concentration, and crystallization. Under optimal conditions $\left(15.0 \mathrm{~g}^{-1}\right.$ of charcoal concentration at $30^{\circ} \mathrm{C}$ for $1 \mathrm{~h}$, with 10 -fold supersaturation cycles of initial concentration, and initial crystallization temperature of $-20^{\circ} \mathrm{C}$ in order to initiate crystal formation and after shifted to $\left.8^{\circ} \mathrm{C}\right)$ to increase the crystallization yield $(43.97 \%)$. After 4 crystallization cycles, xylitol crystallization yields of 76.2 and $68.1 \%$ were obtained in $50 \mathrm{~mL}$ and 5.01 of synthetic broth, respectively. Recovered xylitol had prismatic or orthorhombic needle crystalline structure when ethanol or tetrahydrofuran was used as solvent, and their purity, checked by ${ }^{13} \mathrm{C}$ and ${ }^{1} \mathrm{H}$ nuclear magnetic resonance, mass spectroscopy, and optical rotation, was shown to be almost $99 \%$.

Mussatto and co-workers (54) recovered xylitol from sugarcane bagasse hemicellulosic hydrolyzate fermented by the $C$. guilliermondii yeast by silica gel adsorption and crystallization. In the first step, different ratios of fermented broth volume per gram of silica were employed to pack a stationary phase bed column, and different solvent mixtures of ethyl acetate, ethanol, and acetone were used as eluents. The purified broth was then submitted to different crystallization procedures. The best results $(60 \%$ crystallization yield and $33 \%$ xylitol yield) were obtained when the fractions were combined, concentrated 6.5fold in rotavapor at $50^{\circ} \mathrm{C}$, maintained at $4^{\circ} \mathrm{C}$ for $24 \mathrm{~h}$, and finally seeded with $400 \mathrm{mg}$ of finely ground xylitol.

De Faveri and co-workers (55) studied xylitol recovery from hardwood hemicellulose hydrolyzate fermented by $D$. hansenii containing $75 \mathrm{~g} \mathrm{l}^{-1}$ xylitol and $24 \mathrm{~g} \mathrm{l}^{-1}$ xylose using broth evaporation at $30-50^{\circ} \mathrm{C}, 1.6 \times 10^{4} \mathrm{~Pa}$ and $45-50 \mathrm{rpm}$ until supersaturation was achieved. After addition of $1 \mathrm{~g}^{-1}$ xylitol to favor nucleation, crystallization was carried out by cooling at $-10,-5$, or $0^{\circ} \mathrm{C}$, centrifuging and filtering the solutions, and the results were compared with those obtained with mixed synthetic xylitol/xylose solutions. Promising results both in terms of crystallization yield (56\%) and purity degree (close to $100 \%$ ) were obtained from very concentrated synthetic xylitol solutions $\left(730 \mathrm{~g} \mathrm{l}^{-1}\right)$ at relatively high temperature $\left(-5^{\circ} \mathrm{C}\right)$, whereas the fermented hydrolyzate gave poorer results ( $29 \%$ crystallization yield and $92 \%$ purity) even at lower concentration $\left(470 \mathrm{~g}^{-1}\right)$ and temperature $\left(-10^{\circ} \mathrm{C}\right)$, because of very quick impurity precipitation.

Sampaio and co-workers (44), in a similar study performed on synthetic broth fermented by $D$. hansenii, reported that xylitol crystals with purity in the range $96-97.8 \%$ were produced using xylitol concentrations ranging from 675 to
$911 \mathrm{~g} \mathrm{l}^{-1}$ at $-10^{\circ} \mathrm{C}$, and that an increase in xylitol concentration accelerated xylitol separation by a factor of 14-15. The lower the temperature, the higher the crystallization yield but the lower the crystals purity. The presence of residual xylose, although reducing xylitol percentage in the crystals from 97.7 to $85.3 \%$, increased the crystallization yield from 27 to $42 \%$ and accelerated crystal growth, thereby permitting operation at higher crystallization temperature and lower xylitol concentration.

Rivas and co-workers (45) studied xylitol crystallization from concentrated corncob hydrolyzates previously detoxified with charcoal, fermented by $D$. hansenii, and then subjected to sequential stages of adsorption, concentration, precipitation with hydroalcoholic solutions, and further concentration. At $-5^{\circ} \mathrm{C}$ an increase in ethanol percentage from 40 to $60 \%(\mathrm{v} / \mathrm{v})$ resulted in a progressive rise in the crystallization yield from 15.6 to $47.1 \%$, while at $-10^{\circ} \mathrm{C}$ xylitol content of mother liquors was almost the same, but the crystallization yield was remarkably improved in media treated with 40 and $50 \%$ ethanol, because of both a reduction of viscosity and an acceleration of crystallization. Under optimal conditions, crystallization led to regularly shaped, well-formed, homogeneous crystals containing $98.9 \%(\mathrm{w} / \mathrm{w})$ xylitol.

Martínez and co-workers (19) studied the downstream process for xylitol produced from sugarcane bagasse hemicellulosic hydrolyzate. Preliminary treatment of the hydrolyzate with ion-exchange resin provided a xylose-rich liquor containing $177.8 \%$ xylose and $2.10 \mathrm{~g} \mathrm{l}^{-1}$ glucose, which was fermented by $C$. guilliermondii in a 151 fermenter with $0.48 \mathrm{~g} \mathrm{l}^{-1} \mathrm{~h}^{-1}$ xylitol volumetric productivity, $0.75 \mathrm{~g} \mathrm{~g}^{-1}$ yield, and $81.8 \%$ fermentation efficiency after $132 \mathrm{~h}$. A preliminary crystallization step at $0.5^{\circ} \mathrm{C} \mathrm{min}^{-1}$ cooling rate and $50^{\circ} \mathrm{C}$ saturation temperature allowed obtaining a syrup containing $935.4 \mathrm{~g}^{-1}$ xylitol and $13.1 \mathrm{~g} \mathrm{l}^{-1}$ arabinose and crystals with worse properties $\left(85 \%\right.$ purity, $-147.81 \mathrm{~J} \mathrm{~g}^{-1}$ melting heat, $84.67^{\circ} \mathrm{C}$ melting point, and 3\% moisture content) compared with commercial xylitol $\left(99.8 \%\right.$ purity, $-259.63 \mathrm{~J} \mathrm{~g} \mathrm{~g}^{-1}$ melting heat, $93.61^{\circ} \mathrm{C}$ melting point, and $0.05 \%$ moisture content). A second crystallization step in $50-50 \%(\mathrm{w} / \mathrm{w})$ water/ethanol solutions at different proportions (42.63, 52.98 and $63.59 \mathrm{~g} 100 \mathrm{~mL}^{-1}$ ), saturation temperatures $\left(30,40\right.$, and $\left.50^{\circ} \mathrm{C}\right)$ and cooling rates $\left(0.1,0.25\right.$, and $\left.0.50^{\circ} \mathrm{C} \mathrm{min}^{-1}\right)$, increased crystals purity to 91.20-94.85\%, melting point to $91.8-94.1^{\circ} \mathrm{C}$ and melting heat to $-174.18 /-214.62 \mathrm{~J} \mathrm{~g}^{-1}$ (as an absolute value), and reduced moisture content to $1.55-2.77 \%$. Scanning electron microscopy revealed the occurrence of irregular agglomerates because the random clusters of crystals adhered and interpenetrated one another after growing together.

Canilha and co-workers (47) purified wheat straw hemicellulosic hydrolyzate fermented by $C$. guilliermondii using sequential adsorption on two strongly basic anion-exchange resins (A-860S and A-500PS), which considerably reduced the content of soluble by-products (by up to 97.7\%) and medium color (by $99.5 \%$ ), but simultaneously increased xylitol 
loss, even though up to a still acceptable level (21.1\%). After medium clarification with resins, vacuum concentration in ethanol solution at $50^{\circ} \mathrm{C}$ saturation temperature and $0.2-0.4^{\circ} \mathrm{C}$ $\mathrm{min}^{-1}$ cooling rate, and mixing the concentrated medium ( 0 , 30 , and $50 \%$ ) with a commercial xylitol solution $(100,70$, and $50 \%$ ), these authors were successful obtaining xylitol crystals with up to $99.9 \%$ purity without any medium concentration at $100 \%$ xylitol solution and $95.3-95.9 \%$ purity at $30-50 \%$ medium concentration and $50-70 \%$ xylitol solution. Crystals presented a much more defined geometry than those obtained from mixtures containing wheat straw-derived medium and pure xylitol.

Martínez and co-workers (15) proposed a two-step protocol for xylitol crystallization from a semisynthetic medium fermented by $C$. guilliermondii (61.3 $\mathrm{g} \mathrm{l}^{-1}$ xylitol), centrifuged and concentrated to produce a syrup with $745.3 \mathrm{~g} \mathrm{l}^{-1}$ xylitol. A preliminary crystallization step, carried out at 1.17 supersaturation, saturation temperature of $50^{\circ} \mathrm{C}$, and a $0.5^{\circ} \mathrm{C} \mathrm{min}^{-1}$ cooling rate, was followed by a second step of seeding with $0.1 \%$ xylitol crystals $\left(95 \%\right.$ purity, $-206.71 \mathrm{~J} \mathrm{~g}^{-1}$ melting heat, $91.5^{\circ} \mathrm{C}$ melting point, and $3.08 \%$ moisture content) at $0.25^{\circ} \mathrm{C} \mathrm{min}{ }^{-1}$ and different saturation temperatures $\left(30-50^{\circ} \mathrm{C}\right)$. The lowest saturation temperature $\left(30^{\circ} \mathrm{C}\right)$ ensured the highest nucleation rate $\left(4.58 \times 10^{7} \mathrm{~m}^{-3} \mathrm{~s}^{-1}\right)$, but the crystallization lasted the longest $(3,982.8 \mathrm{~s})$, whereas the highest crystal growth rate $\left(5.15 \times 10^{-8} \mathrm{~m} \mathrm{~s}^{-1}\right)$ and the largest mean size $\left(93.975 \times 10^{-4} \mathrm{~m}\right)$ were obtained at $40^{\circ} \mathrm{C}$. At the end of the process, agglomerates and hexagonal xylitol crystals with $98.5-99.2 \%$ purity, $-236.8 /-$ $244.95 \mathrm{~J} \mathrm{~g}^{-1}$ melting heat, and $93.9-94.1^{\circ} \mathrm{C}$ melting point were obtained.

\section{FUTURE PERSPECTIVES}

The increase in demand for xylitol in the food and pharmaceutical market has intensified research for the development of a low cost xylitol production process. Different biomasses can be used as abundant and cheap feedstocks for the production of xylitol from xylose by fermentation. Crystallization is a purification method that leads to crystals with high purity and uniform size; however, optimal protocols to perform this operation are strongly dependent on the raw material and appear to be a rather long-term goal that will require more effort.

\section{CONCLUSIONS}

Conversion of lignocellulosic materials into high value products using acid or enzymatic hydrolysis and subsequent fermentation are economically viable and ecologically friendly usages. Biotechnological production of xylitol is a very promising alternative to the present chemical technique because it is simpler, uses less energy, and is less polluting. However, the conversion of biomass to fermentable sugars is quite troublesome. More research needs to be done to develop efficient pretreatment methods to find enzymes that perform hemicellulose conversion, to genetically improve strains able to ferment hemicellulosic sugars, and to find protocols for effective xylitol recovery from fermented broths. This overview on xylitol recovery showed that residual sugar in fermented hydrolyzates influences the purity of crystals and the crystallization yield and that xylitol yield can be substantially improved by processing of mother liquors through successive crystallization steps. The cooling profile, initial supersaturation level, final temperature, crystallization time, and seeding protocol all play important roles in the process; therefore, the search for optimal crystallization conditions is fundamental to maximize the efficiency of the overall process. Of the different attempts reported in the literature to recover xylitol, the treatment of fermented broth with activated charcoal followed by vacuum concentration and crystallization by cooling was undoubtedly the best protocol to produce xylitol crystals from synthetic xylose solutions. As far as the structure of xylitol crystals is concerned, electron microscopic studies revealed hexagonal shape in the absence of solvents or irregular forms, while in organic solvents the shape of xylitol crystals varies according to the solvent, ethanol leading to a prismatic structure and tetrahydrofuran to orthorhombic needles.

\section{FUNDING}

This work was supported by Fundação de Amparo à Pesquisa do Estado de São Paulo (FAPESP) and Conselho Nacional de Desenvolvimento Científico e Tecnológico (CNPq), Brazil.

\section{REFERENCES}

1. Grillaud, M., Bandon, D., Nancy, J., Delbos, Y., Vaysse, F. (2005) Les polyols in pedriatic dentristry. Arch. Pedriatrie, 12: 1180.

2. Itawa, C., Nakagaki, H., Sekita, T., Goshima, M., Abe, T. (2003) Daily use of dentrifrice with and without xylitol and fluoride: Effect of glucose retention in humans in vivo. Arch. Oral Biol., 48: 389-395.

3. Uhari, M., Kontiokari, T., Niemela, M. (1998) A novel use of xylitol sugar on preventing acute otitis media. Pedriatics, 102: 879.

4. Rodrigues, R. C. B., Canettieri, E. V., Martinez, E. A., Canilha, L., Solenzal, A. I. N., Almeida e Silva, J. B. (2012) Statistical approaches for the optimization of parameters for biotechnological production of xylitol. In: D-Xylitol; Silva, S. S., Chandel, A. K., eds.; Springer-Verlag: Berlin; pp. 133-160.

5. Winkelhausen, E., Kusmanova, S. (1998) Microbial bioconversion of D-xylose to xylitol. J. Ferment. Bioeng., 86(1): 1.

6. Mussatto, S. I., Roberto, I. C. (2004) Alternatives for detoxification of diluted-acid lignocellulosic hydrolysates for use in fermentative process: A review. Biores. Technol., 93: 1.

7. Aliakbarian, B., De Faveri, D., Perego, P., Converti, A. (2012) An assessment on xylitol recovery methods. In: D-Xylitol; Silva, S. S., Chandel, A. K., eds.; Springer-Verlag: Berlin; pp. 229-244.

8. Wolfrom, M. L., Kohn, E. J. (1942) Crystalline Xylitol. J. Amer. Chem. Soc., 64(7): 1739.

9. Carson, J. F., Waisbrot, S. W., Jones, F. T. (1943) A new form of crystalline xylitol. J. Am. Chem. Soc., 65(2): 1777.

10. Kim, H. S., Jeffrey, G. A. (1969) The crystal structure of xylitol. Acta Cryst., B25: 2607.

11. Reamy, A., Schweizer, F. (1983) Thermal behavior of carbohydrates studies by heat flow calorimetry. J. Therm. Anal. Calorim., 28(1): 95. 
12. Carpentier, L., Desprez, S., Descamps, M. (2003) Crystallization and glass properties of pentitols xylitol, adonitol, arabitol. J. Therm. Anal. Calorim., 73: 577.

13. Seppälä, A., Meriläinen, A., Wikström, L., Karuranen, P. (2010) The effect of additives on the speed of the crystallization front of xylitol with various degrees of supercooling. Exp. Therm. Fluid Sci., 34: 523.

14. Nurmi, J., Heikkilä, H., Halttunen, H., Perkkalainen, P., Pitkänen, I. Composition comprising co-crystals, method for its manufacture, and its use. Patent WO 96/07331, March 16, 1996.

15. Martínez, E. A., Giulietti, M., Almeida e Silva, J. B., Derenzo, S., Felipe, M. G. A. (2009) Batch cooling crystallization of xylitol produced by biotechnological route. J. Chem. Technol. Biotech., 84: 376.

16. Tong, B.; Tan, Z. C.; Shi, Q.; Li, Y. S.; Yue, D. T.; Wang, S. X. (2007) Thermodynamic investigation of several natural polyols (I): Heat capacities and thermodynamic properties of xylitol. Thermochim. Acta, 457: 20.

17. Vyglazov, V. V., Khol'kin, Y. I. (1984) Solubility in the system xylitol-ethanol-water and certain properties of saturated solutions. Zhurnal Prikladnoi Khimi, 57(7): 1651.

18. Nývlt, J., Hostomský, J., Giulietti, M. (2001) Cristalização, Ed. da UFSCar, São Carlos. 160p.

19. Martínez, E. A., Almeida e Silva, J. B., Giulietti, M., Solenzal, A. I. N. (2007) Downstream process for xylitol produced from fermented hydrolysate. Enz. Microb. Technol., 40: 1185.

20. Nývlt, J., Sönhel, O., Matuchová, M., Broul, M. (1985) The Kinetics of Industrial Crystallization; Academia: Prague.

21. Glasgow, S. M. Crystallization, In: Fermentation and Biochemical Engineering Handbook; Vogel, H. C.; Noyes Publications: Park Ridge, p. 277.

22. Melaja, A. J., Hämäläinem, L. Process for making xylitol. U.S. Patent 4.008.285, February 15, 1977.

23. Munir, M., Schiweck, H. Process for recovering xylitol from end syrups of the xylitol crystallization. U.S. Patent 4,246,431, January 20, 1981.

24. Vourinen, T. Production of xylitol. U.S. Patent 5,563,303, October 8 , 1996.

25. DuRoss, J. W. Melt crystallized xylitol. U.S. Patent 5,139,795, August $18,1992$.

26. Heikkilä, H., Puuppo, O., Tylli, M., Nikander, H., Nygrèn, J., Lindroos, M., Eroma, O. P. Method for producing xylitol. Patent WO97/49659, June 23, 1997.

27. Fernandez, C., Avelino, A., Farelo, F. (1999) Crystallization of xylitol from hydro-alcoholic solutions containing arabitol and adonitol. In: 14th International Symposium on Industrial Crystallization, 12-16 September, Cambridge University.

28. Nurmi, J., Eroma, O. P., Eriksson, K. Method for recovering an organic compound from solutions. U.S. Patent 5980640, November 9, 1999.

29. Heikkilä, H., Nygren, J., Sarkki, M. L., Gros, H., Eroma, O. P., Pearson, J., Pepper, T. Crystallization of xylitol, crystalline xylitol product and use thereof. Patent WO 99/59426, May 17, 1999.

30. Vyglazov, V. V. (2004) Kinetics characteristics of xylitol crystallization from aqueous-ethanolic solutions. Russian J. Appl. Chem. 77: 26.

31. Hao, H., Hou, B., Wang, G., Lin, J. K. (2006) Effect of solvent on crystallization behavior of xylitol. J. Crystal Growth, 290: 192.

32. De Faveri, D., Torre, P., Perego, P., Converti, A. (2004) Optimization of xylitol recovery by crystallization from synthetic solutions using response surface methodology. J. Food Eng., 61: 407.

33. Semlali Aouragh Hassani, A., Saidi, K., Bounahmidi, T. (2001) Steady state modeling and simulation of an industrial continuous crystallizer. Comput. Chem. Eng., 25(9-10): 1351.

34. Geiger, O. E. (1997) Statistical methods for fermentation optimization. In: Fermentation and Biochemical Engineering Handbook, 2nd ed.; Vogel, H. C.; Todaro, C. L., eds.; Noyes Publications: Westwood.
35. Liavoga, A. B., Bian, Y., Seib, P. A. (2007) Release of D-xylose from wheat straw by acid and xylanase hydrolysis and purification of xylitol. $J$. Agric. Food Chem., 55: 7758.

36. Martínez, E. A., Almeida e Silva, J. B., Giulietti, M., Derenzo, S. (2008) Kinetics of the xylitol crystallization in hydro-alcoholic solution. Chem. Eng. Process, 47: 2157.

37. Cheng, H., Wang, B., L. V. J., Jiang, M., Lin, S., Deng, Z. (2011) Xylitol production from xylose mother liquor: a novel strategy that combines the use of recombinant Bacillus subtilis and Candida maltosa. Microb. Cell Factories, 10 (5): 1-12.

38. Martínez, E. A., Santos, J. A. F. (2012) Influence of the use of rice bran extract as a source of nutrients on xylitol production. Ciência Tecnol. Alim., 32(2): 308.

39. Counsell, J. N. (1978) Xylitol, Applied Science Publishers: London.

40. Jaffe, G. M. (1978) Xylitol: A specialty sweetener. Sugar Azúcar, 93: 36.

41. Kiysawa, K. (1991) Volumetric properties of polyols (ethylene glycol, glycerol, mesoerythritol, xylitol, and mannitol) in relation to their membrane permeability group 92 additivity and estimation of the maximum radius of their molecules. Biochem. Biophys. Acta, 1064: 251.

42. Sommer, R. (1996) Production of Yeast Extract. In: 9th International Symposium on Yeasts, Sydney.

43. Gurgel, P. V., Mancilha, I. M., Peçanha, R. P., Siqueira, J. F. M. (1995) Xylitol recovery from fermented sugarcane bagasse hydrolysate. Biores. Technol., 52: 219.

44. Sampaio, F. C., Passos, F. M. L., Passos, F. J. V., De Faveri, D., Perego, P., Converti, A. (2006) Xylitol crystallization from culture media fermented by yeasts. Chem. Eng. Process., 45: 1041.

45. Rivas, B., Torre, P., Dominguez, J. M., Converti, A., Parajó, J. C. (2006) Purification of xylitol obtained by fermentation of corncob hydrolysates. J. Agric. Food Chem., 54(12): 4430.

46. Misra, S., Gupta, P., Raghuwanski, S., Dutt, K., Saxena, R. K. (2011) Comparative study on different strategies involved for xylitol purification from culture media fermented by Candida tropicalis. Sep. Purif. Technol., 78: 266.

47. Canilha, L., Carvalho, W., Giulietti, M., Felipe, M. G. A., Almeida e Silva, J. B. (2008) Clarification of a wheat straw-derived medium with ion-exchange resins for xylitol crystallization. J. Chem. Technol. Biotech., 1(83): 715.

48. Heikkilä, H., Nurmi, J., Rahkila, L., Töyrylä, M. Method for the production of xylitol from mixtures containing xylose. Patent WO 90/08193, January $15,1990$.

49. Heikkilä, H., Nurmi, J., Rahkila, L., Töyrylä, M. Method for the production of xylitol. U.S. Patent 5,081, 026, January 14, 1992.

50. Manalo, J. B., Boyles, A., Ambal, W. O., Estrella, R. R. (1992) Production of xylitol from sugar cane bagasse. Philippine J. Sci., 121(1): 181.

51. Wei, J., Yuan, Q., Tianxin, W., Wang, L. (2010) Purification and crystallization of xylitol from fermentation broth of corncob hydrolysates. Front. Chem. Eng. China, 4(1): 57.

52. Affleck, R. P. (2000) Recovery of xylitol from fermentation of model hydrolysate using membrane technology. Master of Science Thesis, State University of Virginia.

53. Belter, P. A.; Cussler, E. L., Hu, W. S. (1988) Bioseparations: Downstream Processing for Biotechnology; Wiley: New York.

54. Mussatto, S. I., Santos, J. C., Filho, W. C. R., Silva, S. S. (2006) A study on the recovery of xylitol by batch adsorption and crystallization from fermented sugarcane bagasse hydrolysate. J. Chem. Techn. Biotechnol. 81: 1840.

55. De Faveri, D., Perego, P., Converti, A., Del Borghi, M. (2002) Xylitol recovery by crystallization from synthetic solutions and fermented hemicellulosic hydrolysates. Chem. Eng. J., 90: 291. 